\title{
The Baltica-Laurentia Connection: Sveconorwegian (Grenvillian) Metamorphism, Cooling, and Unroofing in the Bamble Sector, Norway ${ }^{1}$
}

\author{
Michael A. Cosca, Klaus Mezger, ${ }^{2}$ and Eric J. Essene ${ }^{3}$ \\ Institut de Minéralogie, Université de Lausanne, CH-1015 Lausanne, Switzerland
}

\begin{abstract}
ABS TRACT
The Sveconorwegian Bamble Sector of south Norway is a segment of the high-grade metamorphic basement of the Baltic shield generally considered an integral piece of the global Grenvillian orogenic belt. In particular, the Bamble Sector is generally directly linked to the Grenville Province of North America in middle Proterozoic tectonic reconstructions. However, few high-precision data exist on the metamorphic chronology of the Bamble Sector to test such models. In this paper high precision U-Pb data for monazite, allanite, and titanite indicate that rocks from the Bamble Sector near Arendal underwent granulite facies metamorphism at $~ 1140 \mathrm{Ma}$. A second phase of metamorphism may be indicated by $\mathrm{U}-\mathrm{Pb}$ titanite ages of $\sim 1105 \mathrm{Ma}$, or alternatively these may simply record delayed cooling or growth of titanite below temperatures for significant lead diffusion. Hornblende ${ }^{40} \mathrm{Ar} /{ }^{39} \mathrm{Ar}$ ages indicate cooling of the same rocks below $\sim 550^{\circ} \mathrm{C}$ between 1090 and $1080 \mathrm{Ma}$. Metamorphic cooling rates of $\sim 3^{\circ}-8^{\circ} \mathrm{C} / \mathrm{Ma}$ between $\sim 725^{\circ}$ and $\sim 550^{\circ} \mathrm{C}$, and $\sim 2^{\circ}-4^{\circ} \mathrm{C}$ between $\sim 550^{\circ} \mathrm{C}$ and $\sim 300^{\circ} \mathrm{C}$ are consistent with published models for the retrograde P-T path. Calculated unroofing rates of 0.5 to $1.0 \mathrm{~mm} / \mathrm{a}$ from depths of $\sim 30 \mathrm{~km}$ to $\sim 15 \mathrm{~km}$ may indicate relatively fast initial unroofing of the Bamble metamorphic basement. While slow relative to active orogens like the Alps or Himalaya, such cooling and unroofing rates represent the fastest yet determined for regional metamorphic basement of Grenvillian age. The timing of metamorphism and cooling in the Bamble Sector, when compared to the limited data available for elsewhere in the Baltic shield, indicate that Sveconorwegian metamorphism may not have been synchronous throughout the Baltic shield. However, these data compare favorably with the timing of metamorphism and metamorphic cooling in the Grenville Province of North America, providing strong evidence for tectonic models directly linking Baltica to Laurentia during the middle Proterozoic Sveconorwegian/Grenvillian orogeny.
\end{abstract}

\section{Introduction}

The Bamble Sector of Norway (figure 1), alternatively referred to as the Bamble region, the Bamble Belt, or the Bamble Shear zone, is a part of the Baltic Shield that has attracted numerous researchers and is famous for its often-cited amphibolite-to-granulite transition. The Bamble Sector is an important area linking Baltica with Laurentia (e.g., Barth and Dons 1960; Gower 1985; Gower et al. 1990) and, on a broader scale, plays a key role in tectonic reconstructions of a Precambrian supercontinent (e.g., Dalziel 1991; Hoffman 1991; Moores 1991; Torsvik et al. 1996). Although Baltica can be correlated with Laurentia on the basis of lithological similarities 1998.

${ }^{1}$ Manuscript received October 3, 1997; accepted March 6,

${ }^{2}$ Max-Planck-Institut für Chemie, Postfach 3060, D-55020 Mainz, Germany. Present address: Institut für Mineralogie, Universität Münster, Corresnstr. 2, D-48149 Münster, Germany.

${ }^{3}$ Department of Geological Sciences, University of Michigan, Ann Arbor, Michigan, 48109-1063, USA. and limited paleomagnetic data (e.g., Park 1992; Torsvik et al. 1996), there are surprisingly few highprecision geochronological data from the highgrade metamorphic basement rocks from Baltica that are necessary to test such correlations.

The Baltic Shield including the Bamble Sector has a protracted history of crustal generation and reworking, including several high-grade metamorphic events dating from the Archean (e.g., Gaal and Gorbatchev 1987). A Sveconorwegian (equivalent to Grenvillian) high-grade (granulite facies) metamorphism in the Bamble Sector was initially documented on the basis of $\mathrm{U}-\mathrm{Pb}$ zircon, titanite, allanite, xenotime, and Rb-Sr whole rock ages of 1160$1200 \mathrm{Ma}\left(\mathrm{O}^{\prime}\right.$ Nions and Baadsgaard 1971). However, the significance of these ages was actively debated (e.g., Field and Råheim 1979, 1981, 1983; Weis and Demaiffe 1983; Baadsgaard et al. 1984; Field et al. 1985; Verschure 1985; Hagelia 1989; Smalley 1990; Starmer 1990, 1991). Not until somewhat younger

[The Journal of Geology, 1998, volume 106, p. 539-552] ๑ 1998 by The University of Chicago. All rights reserved. 0022-1376/98/10605-0006\$01.00 
Sveconorwegian ages were obtained from granulite facies gneisses $(\sim 1152 \mathrm{Ma}$ U-Pb zircon overgrowths: Kullerud and Machado 1991) and granulite facies mineral assemblages $(\sim 1070-1100 \mathrm{Ma}$ Sm-Nd mineral isochrons: Kullerud and Dahlgren 1993) was the importance of a high-temperature metamorphic event at approximately $1100 \mathrm{Ma}$ unequivocally demonstrated. While the data of O'Nions and Baadsgaard (1971) and Kullerud and Dahlgren (1993) clearly demonstrate a high-grade metamorphic event at $\sim 1100-1200 \mathrm{Ma}$ in the Bamble Sector, the data are insufficient for adequately documenting the timing of regional metamorphism and cooling. In this paper high-precision $\mathrm{U}-\mathrm{Pb}$ data from monazite, xenotime, allanite and titanite, together with ${ }^{40} \mathrm{Ar} /{ }^{39} \mathrm{Ar}$ data from hornblende, are combined to define the precise timing of Sveconorwegian (Grenvillian) metamorphism and cooling of the Bamble Sector. These data are combined with available petrological constraints to calculate cooling and unroofing rates for the Bamble Sector and are compared with results from the Grenville orogen in North America.

\section{Geology}

The Bamble Sector in south Norway is a narrow NE-SW trending belt of Proterozoic basement along the Skagerrak coast roughly $150 \mathrm{~km}$ in length with a maximum width of about $30 \mathrm{~km}$ (figure 1). It is bound in the northeast by plutonic rocks associated with the late Paleozoic Oslo Rift, and to the west is in fault contact against the Telemark Sector (e.g., Starmer 1985). Rocks in the Bamble Sector are lithologically diverse, but mainly comprise quartzofeldspathic gneisses and amphibolites with lesser metapelites and quartzites and rare marbles and calc-silicate rocks, all metamorphosed from amphibolite to granulite facies, and locally intruded by post-tectonic granites (e.g., Bugge 1943; Touret 1968; Starmer 1985, 1991; Nijland and Maijer 1993). The Bamble Sector has an overall NE-SW structural trend, related to folding and shearing on a regional scale (Starmer 1985).

The Bamble Sector contains an often-cited "classic" example of an amphibolite-to-granulite transition (Bugge 1943; Touret 1971a), occurring within a narrow section near Arendal (figure 1). In addition to an orthopyroxene isograd, a sequence of mineral isograds has been mapped across this transition (Touret 1971a; Nijland and Maijer 1993), and this area has been further subdivided (zones A-D, figure 1) on the basis of lithological and chemical variations (Field and Råheim 1979; Clough and Field 1980; Smalley et al. 1983). Fluid inclusions across this zone become increasingly rich in $\mathrm{CO}_{2}$ (Touret, $1971 b$ ), which together with stable isotope data have been taken as evidence for pervasive mantlederived $\mathrm{CO}_{2}$ or local $\mathrm{CO}_{2}$-rich magmas (Touret 1971b, 1985; Hoefs and Touret 1975; Pineau et al. 1981). A recent stable isotope study across this transition zone concludes that significant mantlederived $\mathrm{CO}_{2}$ is inconsistent with the data, and that the $\mathrm{CO}_{2}$-rich fluid inclusions are the result of lowgrade metamorphic, $\mathrm{H}_{2} \mathrm{O}$-consuming equilibria involving the Arendal lithologies and a mixed $\mathrm{H}_{2} \mathrm{O}$ $\mathrm{CO}_{2}$ fluid (Broekmans et al. 1994).

Estimates for metamorphic temperatures and pressures for the Bamble Sector have generally been obtained from the granulites near Arendal. A detailed study by Nijland and Maijer (1993) across the amphibolite-to-granulite transition zone places the highest metamorphic conditions $\left(840^{\circ} \mathrm{C}, 7.7 \mathrm{kbar}\right)$ on the mainland in zones $\mathrm{B}$ and $\mathrm{C}$ and lower $\mathrm{P}$ and $\mathrm{T}\left(<750^{\circ} \mathrm{C}, 7 \mathrm{kbar}\right)$ in zone A. They interpreted their data in terms of a thermal dome centered near Arendal (figure 1). No evidence was found for a difference in metamorphic P-T conditions between Tromøy and the mainland (separated by the Tromøysund fault), although some evidence is available for slightly higher metamorphic temperatures in the northeastern part of the island (Harlov 1992; Nijland and Maijer 1993).

\section{Samples and Analytical Techniques}

Fresh rock was collected from well-exposed outcrops along the fjords and roadcuts (figures 1 and 2). Sampling was concentrated in the Kragerö and Arendal areas, where some geochronological data were already available. When possible, outcrops were sampled containing lithologies with minerals for both U-Pb and ${ }^{40} \mathrm{Ar} /{ }^{39} \mathrm{Ar}$ age dating. In all cases, the amphiboles for ${ }^{40} \mathrm{Ar} /{ }^{39} \mathrm{Ar}$ dating were sampled from medium-grained amphibolites containing garnet \pm plagioclase \pm clinopyroxene \pm orthopyroxene \pm biotite \pm magnetite \pm ilmenite. Monazite was separated from a metapelite, allanites from amphibolite and pegmatites, and titanites of similar grain size from calc-silicates, marbles and pegmatites. Samples were crushed, and minerals for ${ }^{40} \mathrm{Ar} /$ ${ }^{39} \mathrm{Ar}$ dating were hand-picked from sieved and concentrated aliquots. Samples for U-Pb analyses and feldspars used for common $\mathrm{Pb}$ analyses were further purified using heavy liquids followed by hand picking.

Minerals for U-Pb dating were carefully washed in deionized water. All minerals were spiked with a mixed ${ }^{205} \mathrm{~Pb} /{ }^{233} \mathrm{U}$ tracer before being digested in $3 \mathrm{ml}$ screw-top Teflon PFA ${ }^{\circledR}$ vials inside Parr ${ }^{\circledR}$ 


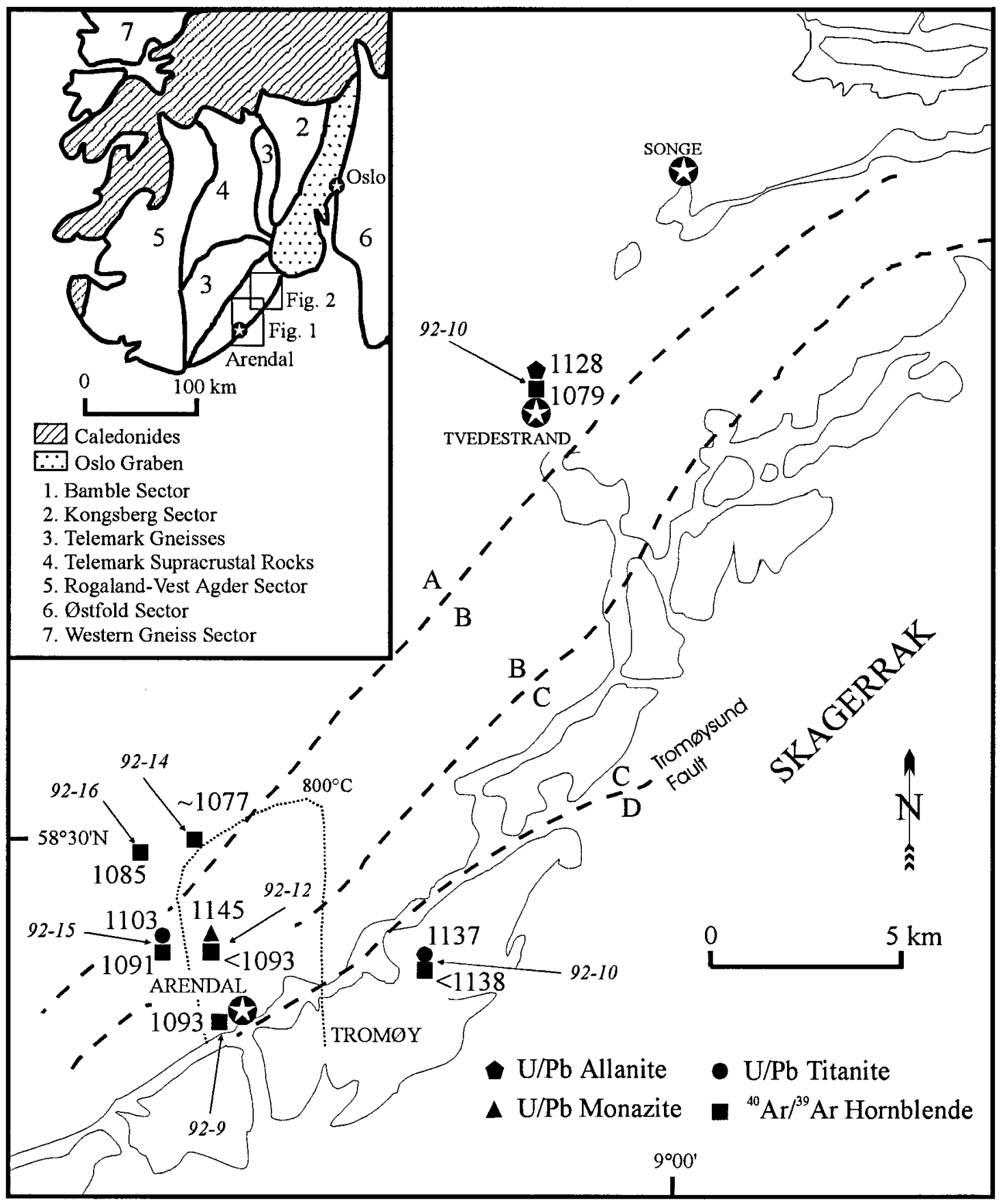

Figure 1. Index and sample location map of the Bamble sector near Arendal showing the distribution of U-Pb and ${ }^{40} \mathrm{Ar} /{ }^{39} \mathrm{Ar}$ mineral ages. Samples with suspected excess argon are indicated as maximum ${ }^{40} \mathrm{Ar} /{ }^{39} \mathrm{Ar}$ ages. Also shown are the Zones A-D of Field and Råheim (1981), which subdivide the region on the basis of an apparent decrease in water activity from west to east. The boundary A-B is the orthopyroxene isograd from Field and Clough (1976), but recent work by Nijland and Maijer (1993) indicates that this isograd is located several kilometers to the west; thus all samples of this study are from the granulite facies. The $800^{\circ} \mathrm{C}$ isograd from Nijland and Maijer (1993) marking one-half of their inferred thermal dome is also indicated. The boundary labeled C-D marks the location of the Tromøysund fault. Map modified from Visser et al. (1992). 


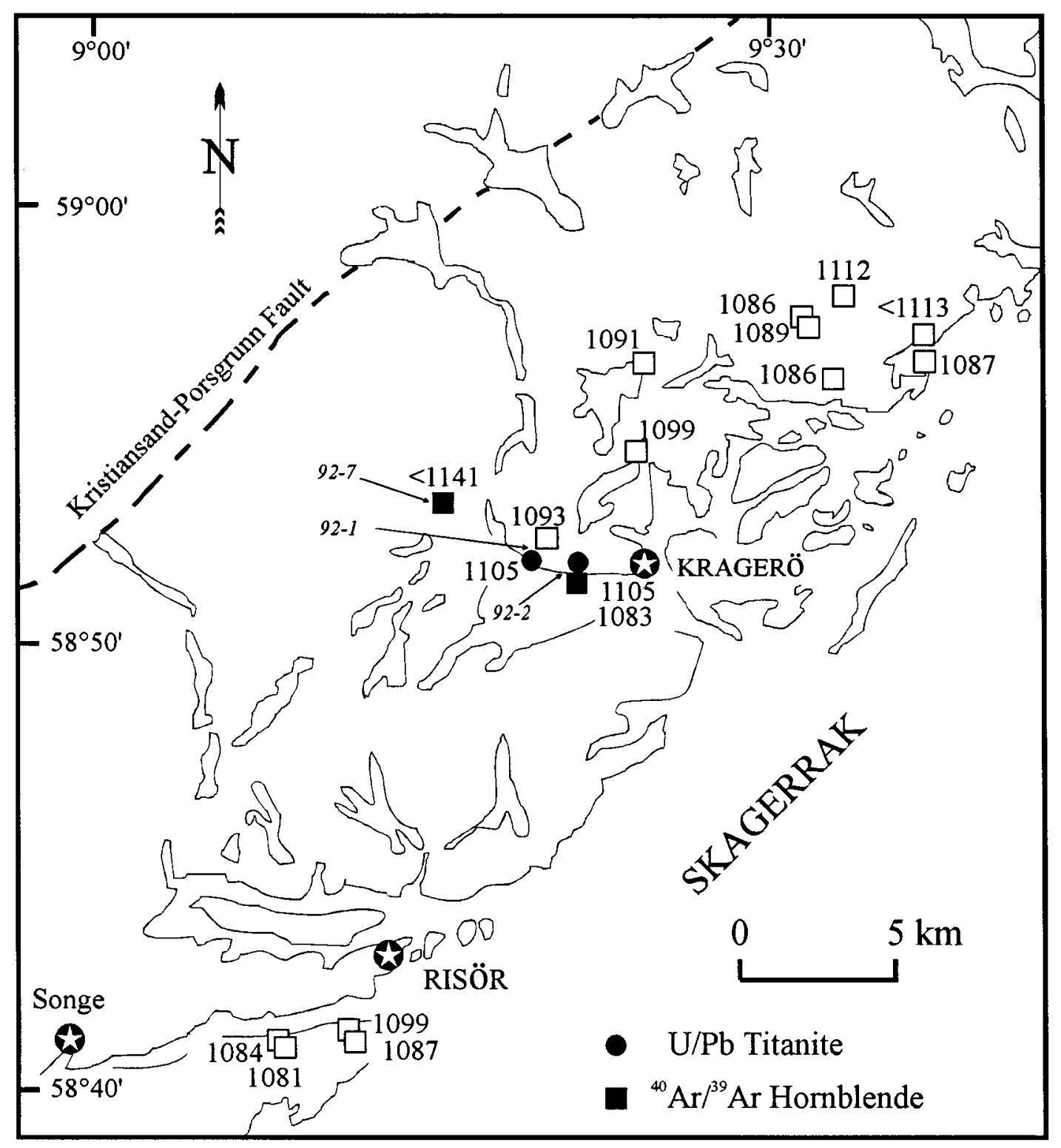

Figure 2. Sample location map of the Bamble sector near Kragerö showing sample locations and the distribution of $\mathrm{U}-\mathrm{Pb}$ and ${ }^{40} \mathrm{Ar} /{ }^{39} \mathrm{Ar}$ mineral ages. Also included are the hornblende ${ }^{40} \mathrm{Ar} /{ }^{39} \mathrm{Ar}$ age results from Cosca and $\mathrm{O}^{\prime} \mathrm{Nions}$ (1994) shown by the open squares. Map modified after O’Nions et al. (1969a).

bombs at $210^{\circ} \mathrm{C}$. The minerals were dissolved in a mixture of concentrated $\mathrm{HF}$ and $\mathrm{HNO}_{3}$. After evaporation, the material was dissolved in $2 \mathrm{M} \mathrm{HCl}$ for ion exchange chromatography. The $\mathrm{Pb}$ was separated using $\mathrm{HCl}-\mathrm{HBr}$ chemistry and the $\mathrm{U}$ by $\mathrm{HCl}$ $\mathrm{HNO}_{3}$ chemistry using BioRad 1-X8 resin (Tilton 1973; Manhès et al. 1984; Mattinson 1986). About 10 to $20 \mathrm{mg}$ of hand-picked $\mathrm{K}$-feldspar or plagioclase separates (ca. 80 mesh) were leached sequentially in $\mathrm{HCl}-\mathrm{HNO}_{3}$ (>6 hrs) and 10 to $20 \% \mathrm{HF}$ (30 min) prior to dissolution in HF. The procedure is described in more detail in DeWolf and Mezger (1994). For isotope measurements, $\mathrm{Pb}$ and $\mathrm{U}$ were loaded separately on single Re filaments using the phosphoric acid-silica gel technique (Cameron et al. 1967). The total procedural blank for $\mathrm{Pb}$ was ca. $30 \mathrm{pg}$ and $<20 \mathrm{pg}$ for $\mathrm{U}$. All $\mathrm{Pb}$ isotope ratios were corrected with a mass discrimination factor of $0.13 \%$ per AMU based on analyses of NBS standard SRM 982. Replicate analyses of NBS-SRM U-500 yielded a discrimination factor for $U$ of $0.13 \%$ per AMU. Decay constants are those recommended by the International Union of Geological Sciences (Steiger and Jäger 1977). For common $\mathrm{Pb}$ corrections, the values from leached feldspars (table 2) were used. The uncertainties reported for all the ra- 
tios $(2 \sigma)$ include the reproducibility of the standard and blank corrections as well as within-run uncertainties and the uncertainties in the U-Pb of the spike. All data were reduced using an algorithm based on the program Pb-DAT (Ludwig 1980, 1982).

The ${ }^{40} \mathrm{Ar} /{ }^{39} \mathrm{Ar}$ analyses were made at the Unversité de Lausanne. Samples, together with the standards, were irradiated for $60 \mathrm{MWH}$ in the central thimble position of the Triga reactor in Denver, Colorado (Dalrymple et al. 1981). The samples were incrementally heated in the furnace, and the gas was expanded and purified using activated $\mathrm{Zr} / \mathrm{Ti}$ / $\mathrm{Al}$ getters and a metal cold finger maintained at liquid nitrogen temperatures. All analyses were made using a low blank, double vacuum resistance furnace and metal extraction line connected to a MAP 215-50 mass spectrometer equipped with a Faraday detector and electron multiplier. Time zero regressions were fit to data collected from seven scans over the mass range 40 to 36 . Peak heights above backgrounds were corrected for mass discrimination, isotopic decay, and interfering $\mathrm{Ca}-, \mathrm{K}-$, and $\mathrm{Cl}-$ derived isotopes of Ar. Blanks were measured at temperature and subtracted from the sample signal. For mass 40, blank values ranged from $4 \times 10^{-15}$ moles below $1350^{\circ} \mathrm{C}$ to $9 \times 10^{-15}$ moles at $1650^{\circ} \mathrm{C}$. Blank values for masses 36-39 were below $2 \times 10^{-17}$ moles for all temperatures. Isotopic production ratios for the Triga reactor were determined from analyses of irradiated $\mathrm{CaF}_{2}$ and $\mathrm{K}_{2} \mathrm{SO}_{4}$ and found to be within error of those reported by Dalrymple et al. (1981). Correction for the neutron flux was determined with an intra-laboratory precision of $0.25 \%$ using the standard MMHB-1, assuming an age of 520.4 Ma (Samson and Alexander, 1987). A mass discrimination correction of $1.008 \mathrm{amu}$ was
Table 2. $\mathrm{Pb}$ Isotope Composition of K-feldspar Residues

\begin{tabular}{lccc}
\hline Sample & ${ }^{206} \mathrm{~Pb} /{ }^{204} \mathrm{~Pb}$ & ${ }^{207} \mathrm{~Pb} /{ }^{204} \mathrm{~Pb}$ & ${ }^{208} \mathrm{~Pb} /{ }^{204} \mathrm{~Pb}$ \\
\hline $92-11$ & 17.678 & 15.583 & 36.740 \\
$92-20$ & 17.356 & 15.516 & 36.736 \\
\hline
\end{tabular}

determined by online measurement of air and was applied to the data.

\section{Results}

The U-Pb and ${ }^{40} \mathrm{Ar} /{ }^{39} \mathrm{Ar}$ data are given in tables 13 (table 3 is available from The Journal of Geology's Data Depository upon request) and shown in figures 3 and 4, respectively (all errors represent $2 \sigma$ uncertainties). The oldest age based on the U-Pb system is recorded in monazite from sample 9212c, a garnet-sillimanite-quartz-biotite metapelite occurring just north of Arendal. This is the only monazite we analyzed here and, as shown in figure 3 , it is slightly above concordia, quite typical for monazite because it can incorporate excess ${ }^{230} \mathrm{Th}$ (derived from the decay of $\mathrm{U}$ ) during growth (e.g., Parrish 1990). Any secondary disturbance causes $\mathrm{Pb}$ loss in monazite just as in zircon. In monazite this results in a closer approach to discordia and, if disturbance is severe, the monazite becomes normally discordant. Because the monazite plots above concordia it can be safely assumed that it was not disturbed. In this case the ${ }^{235} \mathrm{U} /{ }^{207} \mathrm{~Pb}$ age is the most likely age of crystallization because excess Th does not effect this ratio. Because of its high closure temperature to $\mathrm{Pb}$ diffusion $\left(\sim 725^{\circ} \mathrm{C}\right.$, Parrish 1990), and the interlayering of metapelites with granulites, the age of $1145 \pm 3 \mathrm{Ma}$ is interpreted as the

Table 1. Analytical Data for U-Pb Experiments

\begin{tabular}{|c|c|c|c|c|c|c|c|c|c|c|c|c|c|}
\hline Sample ${ }^{a}$ & $\begin{array}{c}\mathrm{U} \\
(\mathrm{ppm})\end{array}$ & $\begin{array}{c}\mathrm{Pb} \\
(\mathrm{ppm})\end{array}$ & $\begin{array}{l}{ }^{206} \mathrm{~Pb} / \\
{ }^{204} \mathrm{~Pb}^{\mathrm{b}}\end{array}$ & $\begin{array}{l}{ }^{208} \mathrm{~Pb} / \\
{ }^{206} \mathrm{~Pb}^{\mathrm{c}}\end{array}$ & $\begin{array}{l}{ }^{207} \mathrm{~Pb} / \\
{ }^{206} \mathrm{~Pb}^{\mathrm{c}}\end{array}$ & & $\begin{array}{l}{ }^{207} \mathrm{~Pb} / \\
{ }^{235} \mathrm{U}\end{array}$ & & $\begin{array}{c}{ }^{206} \mathrm{~Pb} / \\
{ }^{238} \mathrm{U}\end{array}$ & & $\begin{array}{l}{ }^{206} \mathrm{~Pb} / \\
{ }^{238} \mathrm{U} \\
(\mathrm{Ma})\end{array}$ & $\begin{array}{c}{ }^{207} \mathrm{~Pb} / \\
{ }^{235} \mathrm{U} \\
(\mathrm{Ma})\end{array}$ & $\begin{array}{c}{ }^{207} \mathrm{~Pb} / \\
{ }^{206} \mathrm{~Pb} \\
(\mathrm{Ma})\end{array}$ \\
\hline $1 \mathrm{~A}$ & & & 9 & 25.29 & 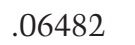 & 111 & .6657 & $(20)$ & .07448 & $(13)$ & fOS & 18 & 769 \\
\hline 2 All & 207. & & 130.5 & 6.51 & .07351 & (20) & 1.417 & (5) & .1398 & (2) & 844 & 896 & 1028 \\
\hline 3 All 9 & 293.2 & 796 & 322.8 & 16.32 & .07651 & (9) & 1.875 & (5) & .1778 & (7) & 1055 & 1072 & 1108 \\
\hline 4 All 92-20/3 & 286.2 & 821.2 & 523.3 & 17.12 & .07727 & (19) & 1.923 & (14) & .1805 & (13) & 1070 & 1089 & 1128 \\
\hline $5 \mathrm{Mz} 92-12 \mathrm{c}$ & 1889 & 1714 & 7336 & 4.297 & .077779 & (3) & 2.089 & (5) & & (8) & 1147 & 1145 & 1141 \\
\hline $6 \mathrm{Sph}$ & 120.7 & 37. & & & .076371 & (12) & 1.967 & (6) & & 5) & & & 1105 \\
\hline $7 \mathrm{Sph}$ & & 23. & & & & (9) & 2.0 & 16 & & ) & & & 1137 \\
\hline $8 \mathrm{Spl}$ & 2 & & & & & (1 & & (7) & & ) & & & 3 \\
\hline $9 \mathrm{Sph}$ & 353.4 & 10 & & & & (15) & & (7) & & (5) & 11 & 3 & 1104 \\
\hline $10 \mathrm{Sph}$ & 370.4 & & & & .07 & (11) & & (8) & & (7) & & & \\
\hline 11 Sph $92-2 a / 3$ & 294.2 & 110.9 & 107.7 & 0.49326 & .076454 & (25) & 1.963 & (10) & .1862 & (9) & 1101 & 1103 & 1107 \\
\hline
\end{tabular}

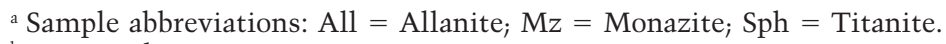

${ }^{\mathrm{b}}$ Measured ratios.

${ }^{\mathrm{c}}$ Corrected for fractionation, blank, and common $\mathrm{Pb}$. 

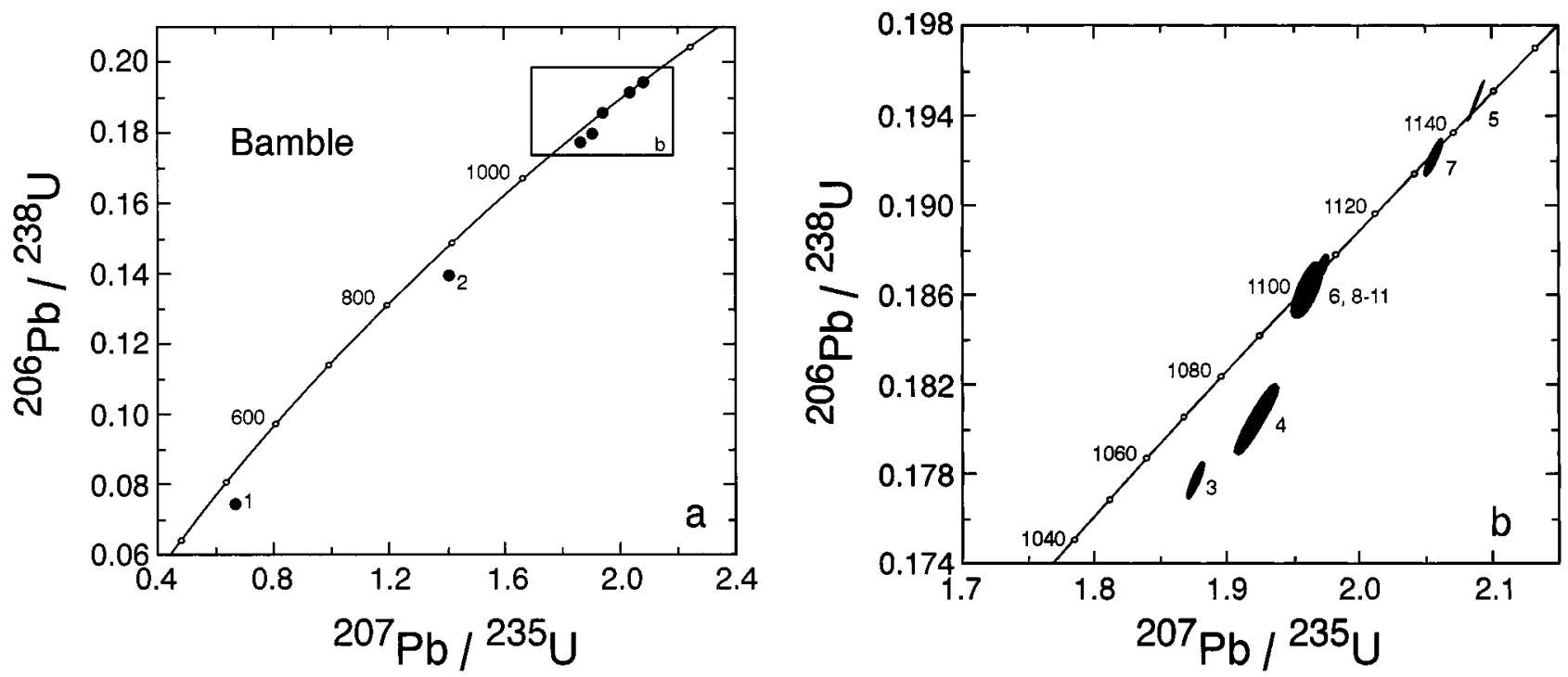

Figure 3. U-Pb concordia diagrams $(a=$ all data; $b=$ enlargement $)$ with ages for monazite, titanite, and allanite. The allanites are discordant and indicate a thermal disturbance possibly during the Permian. The sample numbers on the figure correspond to those given in table 1 .

time of monazite growth and the approximate time of peak metamorphism in these rocks. This interpretation is also supported by the oldest titanite age of $1137 \pm 2 \mathrm{Ma}$, determined from a marble on Tromøy (sample 92-10a) and allanites from a posttectonic pegmatite near Tvedestrand (sample 9220 ), which gave a minimum $207 \mathrm{~Pb} / 206 \mathrm{~Pb}$ age of $1128 \mathrm{Ma}$. Rigorous interpretation of the allanite data is not possible at this stage. In general it is thought that pristine allanite has a very high closure temperature, possibly higher than titanite (e.g., Tuccillo et al. 1992; Mezger et al. 1993). However, the allanites from sample 92-4 (a garnet-bearing amphibolite) and 92-20 are completely metamict and were affected by severe $\mathrm{Pb}$ loss well after formation. The cause of $\mathrm{Pb}$ loss from these minerals is unclear, but lower intercept ages indicate a Permian to recent disturbance to the U-Pb system. This $\mathrm{Pb}$ loss may be the result of thermal effects related to activity along the Oslo Rift but may also be due to leaching of lead from the fragile glassy metamict allanites during recent weathering.

All of the U-Pb titanite ages are younger than the monazite age (1145 Ma), consistent with their expected closure temperatures for the U-Pb system. Only titanite from marble on Tromøy, with an age of $1137 \mathrm{Ma}$, has an age approaching that of the monazite. Titanite from a carbonate vein near Arendal (92-15), and titanites from a pegmatite (92-2) and a calc-silicate (92-1) near Kragerö, yielded statistically indistinguishable ages of $1105 \pm 2 \mathrm{Ma}$. It is now thought that in slowly cooled terranes the closure temperature for lead diffusion in titanite is around $650^{\circ} \mathrm{C}$ (Mezger et al. 1991, 1993; Cherniak 1993). Therefore, the difference of $33 \mathrm{Ma}$ in titanite ages is significant and either indicates later metamorphism near Kragerö, non-uniform cooling and/ or unroofing within the Bamble Sector, or growth of titanite at temperatures below significant lead diffusion around $1100 \mathrm{Ma}$.

Of the nine hornblende samples analyzed (figure 4), five yielded ${ }^{40} \mathrm{Ar} /{ }^{39} \mathrm{Ar}$ age plateaus meeting the criteria given in Cosca et al. (1991). One amphibolite sample from near Kragerö (92-2) gave a hornblende ${ }^{40} \mathrm{Ar} /{ }^{39} \mathrm{Ar}$ plateau age of $1083 \pm 5 \mathrm{Ma}$, consistent with the ${ }^{40} \mathrm{Ar} /{ }^{39} \mathrm{Ar}$ hornblende ages given in Cosca and O'Nions (1994) from the same region. A second hornblende from amphibolite near Kragerö (92-7) yielded a saddle-shaped ${ }^{40} \mathrm{Ar} /{ }^{39} \mathrm{Ar}$ spectrum with a total gas age of $1141 \mathrm{Ma}$, interpreted to contain excess ${ }^{40} \mathrm{Ar}$. The maximum age for this sample is taken as the minimum of the saddle, or $1093 \pm$ $6 \mathrm{Ma}$. Four hornblende samples from near Arendal $(92-20,-16,-15,-9)$ yielded ${ }^{40} \mathrm{Ar} /{ }^{39} \mathrm{Ar}$ plateau ages of $1079 \pm 5 \mathrm{Ma}, 1085 \pm 5 \mathrm{Ma}, 1091 \pm 5 \mathrm{Ma}$, and 1093 $\pm 5 \mathrm{Ma}$, respectively. An additional sample near Arendal (92-14) yielded a complex ${ }^{40} \mathrm{Ar} /{ }^{39} \mathrm{Ar}$ spectrum which, together with the $\mathrm{K} / \mathrm{Ca}$ data, indicates probable phyllosilicate contamination and gave a total fusion age of $1062 \mathrm{Ma}$. An imprecise preferred age for this sample, calculated with the heating steps generating nearly $70 \%$ of the radiogenic argon, is $1077 \pm 32 \mathrm{Ma}$. Two other samples (92-10, -12) have saddle-shaped ${ }^{40} \mathrm{Ar} /{ }^{39} \mathrm{Ar}$ spectra consistent with the presence of excess Ar, yielding maximum ages of $1138 \mathrm{Ma}$ and $1093 \mathrm{Ma}$. Isochron plots 

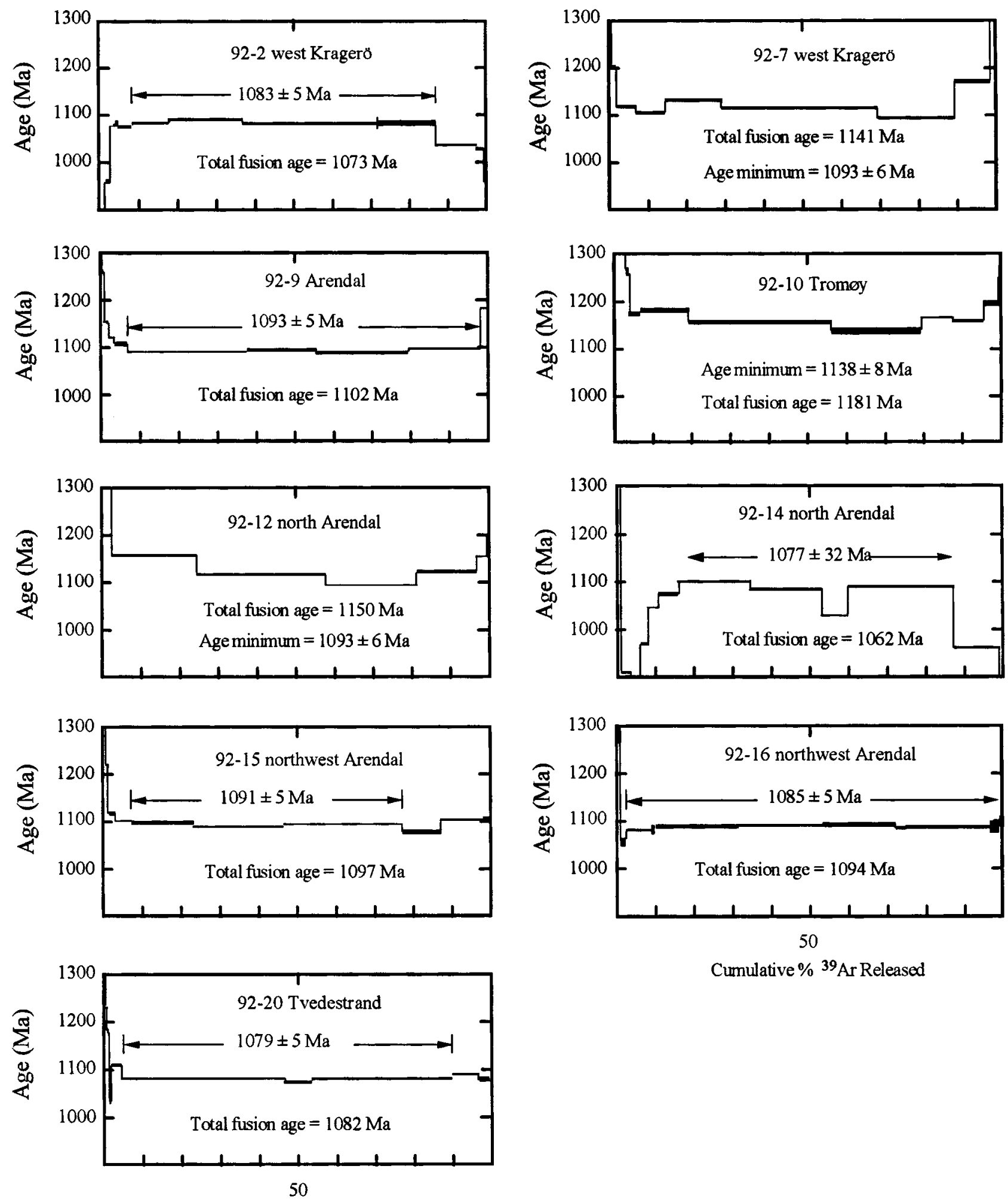

50

Cumulative $\%{ }^{39} \mathrm{Ar}$ Released

Cumulative $\%{ }^{39} \mathrm{Ar}$ Released

Figure 4. Hornblende ${ }^{40} \mathrm{Ar} /{ }^{39} \mathrm{Ar}$ age spectra of hornblendes. 
Figure 5. Temperature-time diagram for coexisting minerals analyzed by $\mathrm{U}-\mathrm{Pb}$ and ${ }^{40} \mathrm{Ar} /{ }^{39} \mathrm{Ar}$. Assumed closure temperatures for given phases are in the text. Hornblende (open square) probably contains excess Ar and therefore represents a maximum age. Also plotted are four hornblende ${ }^{40} \mathrm{Ar} /{ }^{39} \mathrm{Ar}$ ages (Cosca and O'Nions 1994) with co-existing $\mathrm{K} /$ Ar biotite ages $\left(\mathrm{O}^{\prime}\right.$ Nions et al. $1969 b$ ) recalculated with Steiger and Jäger (1977) decay constants. Time of granulite facies metamorphism indicated by monazite, oldest titanite, and allanite ages of 1130-1145 Ma. Titanite $\sim 1105 \mathrm{Ma}$ ages, interpreted as cooling ages, may indicate a second phase of metamorphism, or growth below their closure temperature.

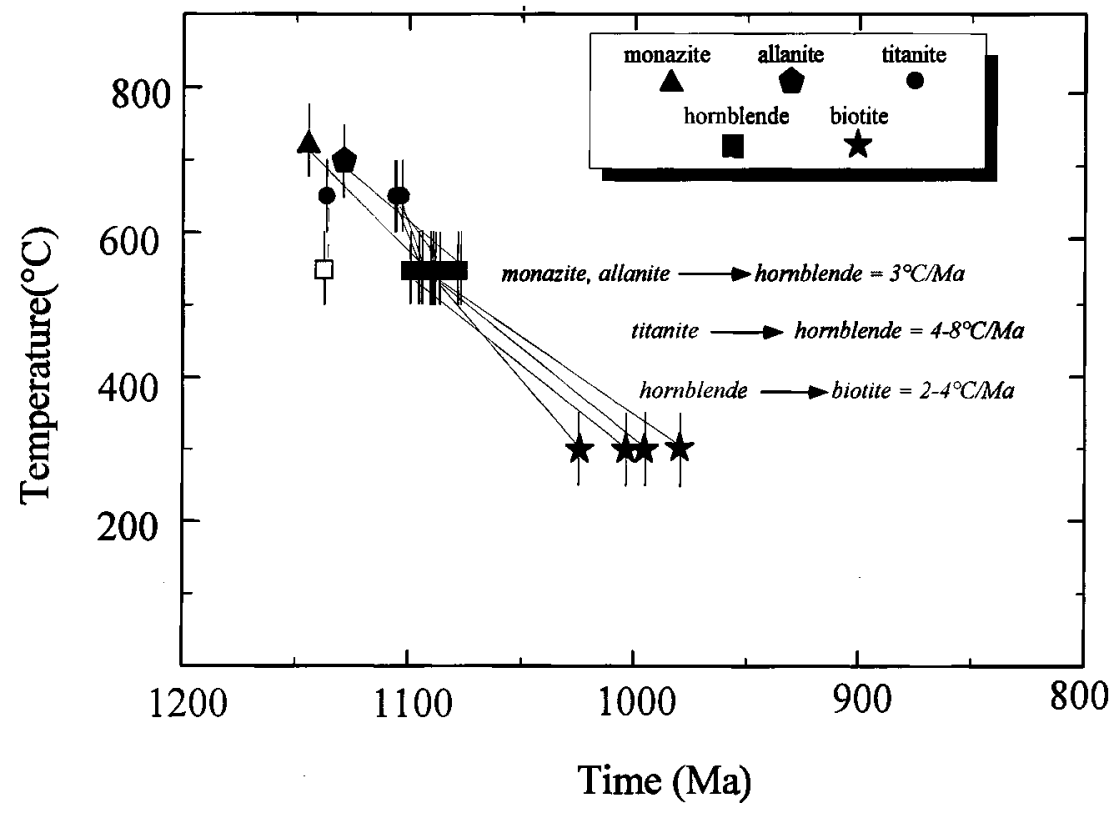

can sometimes be used to evaluate the composition of the trapped argon in minerals not originating from in-situ radioactive decay. However, the very large ${ }^{40} \mathrm{Ar}$ signals relative to the ${ }^{36} \mathrm{Ar}$ signals result in tightly clustered arrays on isochron diagrams, and therefore are not applicable to these samples. Consequently, the composition of the non-radiogenic argon is assumed to have an atmospheric ${ }^{40} \mathrm{Ar} /{ }^{36} \mathrm{Ar}$ ratio (=295.5).

\section{Timing of Metamorphism and Cooling in the Bamble Sector}

The U-Pb ages of monazite (92-12c, $1145 \mathrm{Ma}$ ), titanite $(92-10,1137 \mathrm{Ma})$, and allanite (92-20, upper concordia intercept $1128 \mathrm{Ma}$ ) from near Arendal are the oldest ages obtained in this study (figure 5). The monazite and titanite are interpreted as primary minerals formed during the granulite facies metamorphism, while the allanite is from an undeformed pegmatite that crosscuts the main metamorphic fabric. These observations, together with the high closure temperatures for $\mathrm{Pb}$ diffusion in the minerals dated, are good indications that the mineral ages probably record the thermal peak of granulite facies metamorphism near Arendal. A second titanite from a carbonate vein $(92-15 b)$ near Arendal, with an age of $1103 \mathrm{Ma}$, can be interpreted as either a metamorphic cooling age or a growth age below its closure temperature of $\sim 650^{\circ} \mathrm{C}$. Two titanites dated from near Kragerö give identical $\mathrm{U}-\mathrm{Pb}$ ages of $1105 \mathrm{Ma}$, determined from a calcsilicate (92-1) and a pegmatite (92-2).
The U-Pb mineral ages from this study fall into two groups (figure 5). One group comprises monazite, allanite, and one titanite with ages of 1130$1145 \mathrm{Ma}$, and a second group of three titanites with ages of $\sim 1105 \mathrm{Ma}$. The existence of two distinct groups poses the question of whether the Bamble Sector experienced a protracted granulite metamorphic history, as proposed by Kullerud and Dahlgren (1993), or perhaps underwent distinct phases of granulite facies metamorphism. Given the limited high-precision mineral data it is difficult to distinguish between these different possibilities. The older U-Pb titanite age of $1137 \mathrm{Ma}$ and a coexisting hornblende with apparent excess argon and a maximum ${ }^{40} \mathrm{Ar} /{ }^{39} \mathrm{Ar}$ age of $1138 \mathrm{Ma}$ come from a sample on Tromøy, close to where the maximum metamorphic temperature and pressure conditions were recorded (Nijland and Maijer 1993). The occurrence of the oldest $\mathrm{U}-\mathrm{Pb}$ titanite age on Tromøy may indicate a unique P-T-t history for these rocks relative to those exposed on the mainland. Thus, if the Tromøy samples are not considered, the younger $\mathrm{U}-\mathrm{Pb}$ ages on the mainland give a simple picture of metamorphic cooling below its estimated closure temperature for lead diffusion of $\sim 650^{\circ} \mathrm{C}$ (Mezger et al. 1993; Cherniak 1993) at $\sim 1105 \mathrm{Ma}$. When the Tromøy U-Pb titanite data are considered, the younger $\mathrm{U}-\mathrm{Pb}$ titanite ages could be interpreted as recording either delayed cooling on the mainland, a second phase of metamorphism, or growth of titanite at temperatures below closure to significant lead diffusion. However, there is little evidence to support the interpretation that the $\mathrm{U}-\mathrm{Pb}$ titanite 


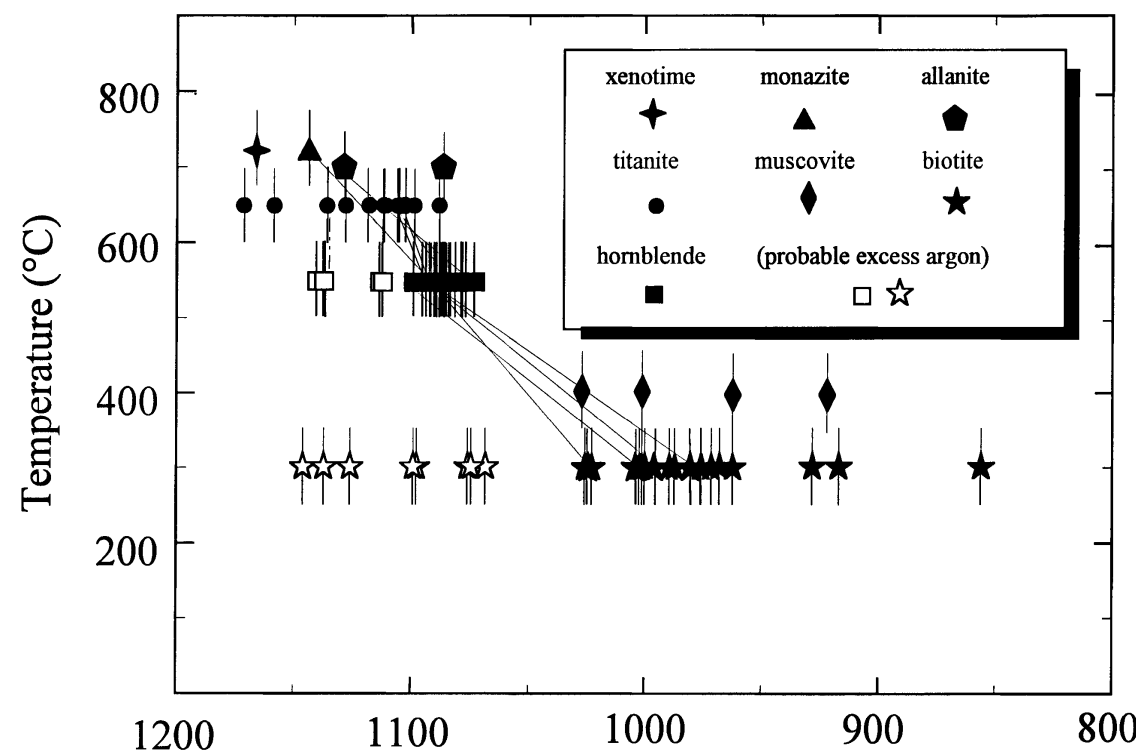

Figure 6. Temperature-time diagram for mineral ages of the Bamble Sector combining data from this study with data from Cosca and O'Nions (1994), and recalculated ages of $\mathrm{O}^{\prime}$ Nions et al. $(1969 \mathrm{~b})$ and O'Nions and Baadsgaard (1971). The combined data, because of difficulties in assigning precise errors to the $\mathrm{U}-\mathrm{Pb}$ analyses given in $\mathrm{O}^{\prime} \mathrm{Nions}$ and Baadsgaard (1971), make direct comparison with U-Pb data of this study difficult. Also shown are the $\mathrm{K} / \mathrm{Ar}$ muscovite and biotite (those with probable excess argon) ages from Andersen et al. (1995) from near Arendal.

\section{Time (Ma)}

ages record growth, rather than simple cooling ages, especially considering that three of three titanites on the mainland, collected from different localities and lithologies, gave identical U-Pb ages within error of $1105 \mathrm{Ma}$. The Tromøysund fault (figure 1), which separates Tromøy from the mainland, may represent the locus of differential uplift and cooling. Without additional high-precision U-Pb mineral data from minerals with higher closure temperatures (like monazites), the interpretation of these ages as differential cooling or sub-closure temperature growth is presently impossible. Nonetheless, the titanite data place a minimum age on granulite facies metamorphism of $1105 \mathrm{Ma}$ in the Kragerö region.

The cooling history is further complicated by consideration of the $\mathrm{U}-\mathrm{Pb}$ data given in $\mathrm{O}^{\prime}$ Nions and Baadsgaard (1971) (figure 6). O'Nions and Baadsgaard (1971) reported several U-Pb titanite ages and individual $\mathrm{U}-\mathrm{Pb}$ allanite and xenotime ages. Using currently accepted decay constants and the data presented in their table, the ${ }^{207} \mathrm{~Pb} /{ }^{206} \mathrm{~Pb}$ ages of these minerals are reduced by 17-22 Ma. Despite their uncharacteristic discordance, the titanite $\mathrm{U}-\mathrm{Pb}$ data of O'Nions and Baadsgaard (1971) are generally consistent with the ages obtained in the present study; notable exceptions include two titanites that indicate minimum ages $\left(={ }^{207} \mathrm{~Pb} /{ }^{206} \mathrm{~Pb}\right.$ ages $)$ of $1166 \mathrm{Ma}$ and $1172 \mathrm{Ma}$. The xenotime age also falls in this range, with a ${ }^{207} \mathrm{~Pb} /{ }^{206} \mathrm{~Pb}$ age of $1166 \mathrm{Ma}$, and O'Nions and Baadsgaard (1971) present an allanite with a discordant ${ }^{207} \mathrm{~Pb} /{ }^{206} \mathrm{~Pb}$ age of $1120 \mathrm{Ma}$. The ages of 1166 to $1172 \mathrm{Ma}$ for the titanite and xenotime samples can be interpreted as implying that high-grade metamorphic conditions may have been reached somewhat earlier than $\sim 1140 \mathrm{Ma}$, as indicated by the geochronological data in this study (figure 6), or $\sim 1152 \mathrm{Ma}$, as suggested by Kullerud and Machado (1991). However, the data given in $\mathrm{O}^{\prime}$ Nions and Baadsgaard (1971) represent some of the first titanites ever dated by the U-Pb method, and differences in early analytical procedures may be a reason for the observed discordance in some of their data. Therefore, more data are needed to confirm these three old ages and evaluate how they may be related to granulite metamorphism.

The high-precision U-Pb mineral ages from this study and the data contained in O'Nions and Baadsgaard (1971) are somewhat older, but nonetheless consistent with the two granulite samples near Arendal that yield $\mathrm{Sm}-\mathrm{Nd}$ mineral isochron ages of 1070-1100 Ma (Kullerud and Dahlgren 1993). This age relationship is consistent with what has been observed elsewhere in the Grenville orogen, where Sm-Nd isochron ages are consistently younger than $\mathrm{U}-\mathrm{Pb}$ titanite ages, implying that $\mathrm{Sm}$ $\mathrm{Nd}$ isochrons have a lower closure temperature (Mezger et al. 1992). The U-Pb ages from the Bamble rocks are also consistent with the hypothesis of Kullerud and Dahlgren (1993) that the intrusion of charnockites at $\sim 1150 \mathrm{Ma}$ (Kullerud and Machado 1991) could have provided the heat source for the high-temperature, medium-pressure Sveconorwegian metamorphism in the Bamble Sector.

The geochronological results from the Bamble Sector may be combined with empirically or experimentally determined closure temperatures to re- 
construct the temperature-time history of the Sveconorwegian metamorphism. For such calculations the following closure temperatures (estimated for grain sizes analyzed and conditions of slow cooling) have been assumed: U-Pb monazite: $\sim 725^{\circ} \mathrm{C}$ (Parrish 1990); U-Pb xenotime: $\sim 725^{\circ} \mathrm{C}$ (assumed); U-Pb allanite: $\sim 700^{\circ} \mathrm{C}$ (Tuccillo et al. 1992); U-Pb titanite: $\sim 650^{\circ} \mathrm{C}$ (Mezger et al. 1993; Cherniak, 1993); K-Ar hornblende: $\sim 500^{\circ} \mathrm{C}$ to $\sim 600^{\circ} \mathrm{C}$ (Harrison 1981; Villa et al. 1996); K-Ar muscovite: $\sim 400^{\circ} \mathrm{C}$ (Kirschner et al. 1996); K-Ar biotite: $\sim 300^{\circ} \mathrm{C}$ (Harrison et al. 1985).

The great majority of the hornblende ${ }^{40} \mathrm{Ar} /{ }^{39} \mathrm{Ar}$ data indicate that the Bamble Sector cooled below its closure temperature to argon diffusion between 1100 and $1080 \mathrm{Ma}$. Assuming the coexisting monazite, allanite, and titanite record cooling ages, they may be combined with the hornblende ages to yield time-integrated cooling rates (figure 5). Previous studies have generally used a closure temperature for Ar diffusion in slowly cooled hornblende of $\sim 500^{\circ} \mathrm{C}$ (Harrison 1981), although recent study indicates that this temperature may be closer to $\sim 600^{\circ} \mathrm{C}$ (Villa et al. 1996). For the present study a value of $550^{\circ} \mathrm{C} \pm 50^{\circ} \mathrm{C}$ is used. Such calculations yield rates of $\sim 3^{\circ} \mathrm{C} / \mathrm{m}$.y., for temperatures between monazite and allanite closure to $\mathrm{Pb}$ diffusion and hornblende closure to Ar diffusion, and $\sim 4$ to $\sim 8^{\circ} \mathrm{C} / \mathrm{m}$.y. (or $\sim 13^{\circ} \mathrm{C} / \mathrm{m}$.y. for a $500^{\circ} \mathrm{C}$ hornblende closure temperature) for the titanite to hornblende cooling interval. Clearly, the relatively rapid titanite to hornblende cooling rates need additional mineral data for confirmation and are significantly faster than those estimated from other high-grade metamorphic basements of similar age and lithologic character (e.g., Cosca et al. 1991; Mezger et al. 1991, 1993). Further calculations with the ${ }^{40} \mathrm{Ar} /{ }^{39} \mathrm{Ar}$ and K-Ar data from Cosca and O'Nions (1994) and O'Nions et al. (1969a, 1969b), yield time integrated rates of $2-4^{\circ} \mathrm{C} / \mathrm{m}$.y. for the time and temperatures between hornblende and biotite closure to Ar diffusion (figure 5), which are similar to rates elsewhere in the North American Grenville Province (Cosca et al. 1991, 1992; Mezger et al. 1991, 1993).

\section{Unroofing History of the Bamble Sector}

The unroofing history of the Bamble Sector may be calculated from the cooling rates given above, together with estimates of the retrograde P-T path. Abundant detailed mineralogical, chemical, and petrological data are available for the Bamble region (e.g., Visser and Senior 1990; Kihle and Bucher-Nurminen 1992; Nijland and Maijer 1993; Nijland et al. 1993; Knudsen 1996). For calculating unroofing rates, we have taken an average model retrograde P-T path from Nijland et al. (1993), who determined peak P-T conditions in the area just north of Arendal to be $\sim 7 \mathrm{kbar}$ and $800^{\circ} \mathrm{C}$. The rocks apparently followed an initial period of near-isobaric cooling $\left(2 \mathrm{bar} /{ }^{\circ} \mathrm{C}\right)$ from the sillimanite field into the kyanite field as evidenced by the presence of kyanite and muscovite veinlets (figure 7). This part of the path was followed by a period of near-isothermal uplift $\left(30 \mathrm{bar} /{ }^{\circ} \mathrm{C}\right)$, constrained by the lack of quartz and the presence of margarite and kyanite, and at lower P-T by the presence of andalusite. A near-isothermal uplift is consistent with evidence from cordierite and orthoamphibole rocks, which include talc-kyanite-quartz, and kyanite-andalusite-chlorite-quartz, and have been interpreted as representing relatively rapid emplacement of these rocks to upper crustal levels (Visser and Senior 1990). Metamorphic basement unroofing, calculated with a retrograde $\mathrm{P}-\mathrm{T}$ path of $30 \mathrm{bar} /{ }^{\circ} \mathrm{C}$, an average crustal density of $2.7 \mathrm{~g} / \mathrm{cm}^{3}$, and the titanite to hornblende cooling rates of $3-8^{\circ} \mathrm{C} / \mathrm{m}$.y., occurred at time-integrated rates of $\sim 0.5$ to $\sim 1.0 \mathrm{~mm} / \mathrm{yr}$ from depths of $\sim 30 \mathrm{~km}$ to $\sim 15 \mathrm{~km}$. The occurrence of late prehnite and pumpellyite, combined with fluid inclusion data by Touret and Olsen (1985), define the lowtemperature and pressure path. The timing for the low-temperature unroofing is poorly known, but the Bamble rocks appear to have remained at depths of $\sim 10 \mathrm{~km}$ until $\sim 200 \mathrm{Ma}$ (e.g., Nijland et al. 1993).

\section{Summary and Implications for Middle Proterozoic Baltica-Laurentia}

The high-precision geochronological data presented here are consistent with Sveconorwegian (Grenvillian) metamorphism in the Bamble Sector of Norway between 1145 to $1100 \mathrm{Ma}$ with a thermal peak of granulite facies at $\sim 1145 \mathrm{Ma}$. The data from this study provide no clear evidence for any regional variation in the metamorphic cooling history of the Bamble Sector, although more mineral age data with high closure temperatures are needed to test this. Following granulite facies metamorphism, average cooling rates varied from $3-8^{\circ} \mathrm{C} /$ m.y. between $\sim 725^{\circ} \mathrm{C}$ and $\sim 550^{\circ} \mathrm{C}$. The faster cooling rates depend on the interpretation that the measured U-Pb titanite ages record metamorphic cooling and not mineral growth below temperatures for lead diffusion. If correct, these cooling rates represent the fastest yet demonstrated for similar metamorphic basement rocks of middle Proterozoic age. Together with a model retrograde P-T path for the Bamble Sector, these cooling rates indicate rela- 


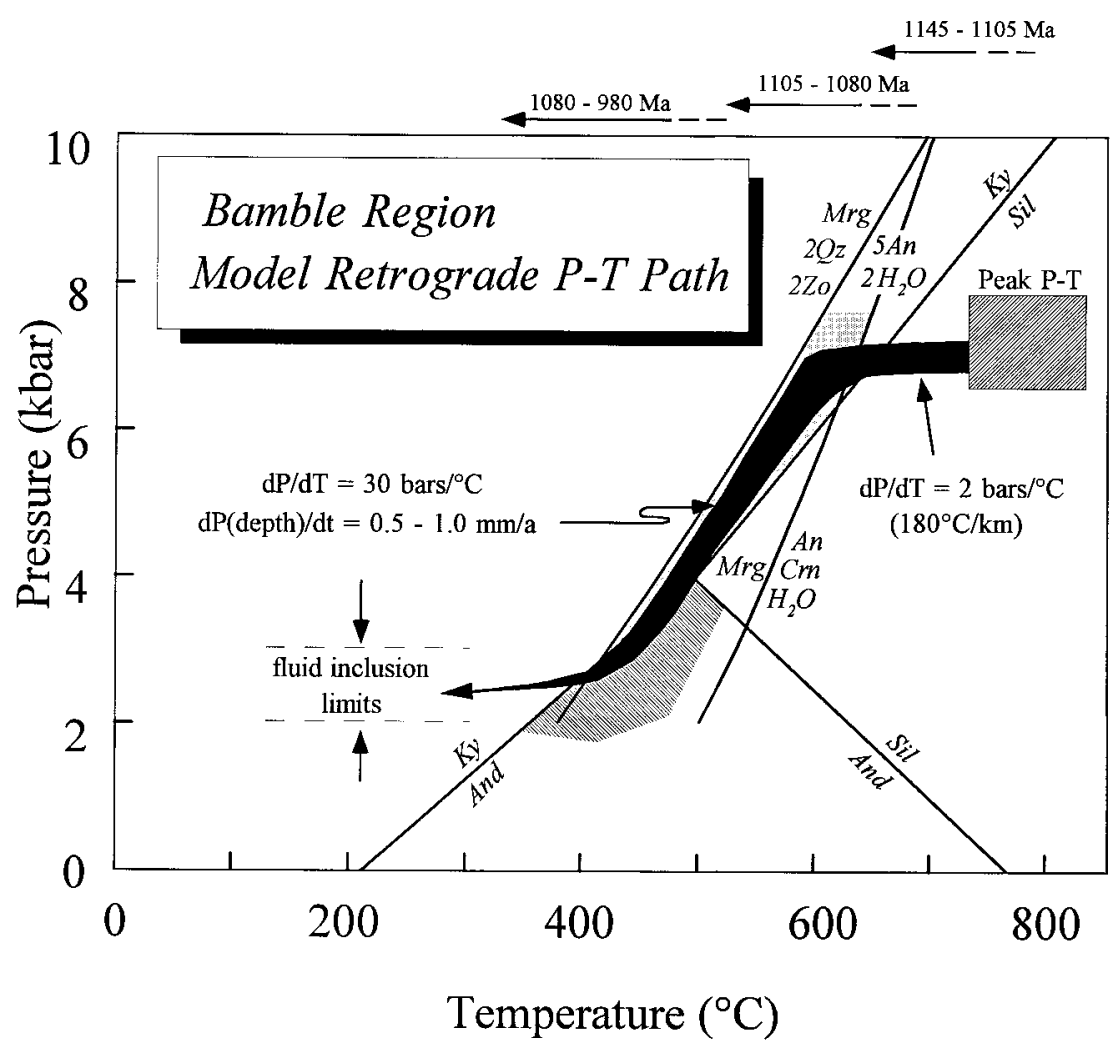

Figure 7. Model retrograde P-T path for rocks of the Bamble Sector, modified after Nijland et al. (1993). The large black arrow shows the likely retrograde path, constrained to the shaded areas by the labeled reactions and stable aluminosilicate, beginning with peak P-T conditions of $\sim 7 \mathrm{~kb}$ and $800^{\circ} \mathrm{C}$ and followed by an initial period of near isobaric cooling $\left(2 \mathrm{bar} /{ }^{\circ} \mathrm{C}\right)$, then a period of near isothermal uplift $\left(30 \mathrm{bar} /{ }^{\circ} \mathrm{C}\right)$. The occurrence of late prehnite and pumpellyite together with fluid inclusion data by Touret and Olsen (1985) define the low-temperature and pressure path. The approximate timing of the P-T conditions experienced by the Bamble Sector rocks as they followed this path is indicated at the top of the figure. tively rapid initial unroofing of the metamorphic basement at 0.5 to $1.0 \mathrm{~mm} / \mathrm{a}$, which is consistent with the preserved mineral parageneses.

Mainly on the basis of lithological similarities, the Sveconorwegian orogen has been linked with the North American Grenville Province in reconstructions of a single cratonic landmass during middle Proterozoic time (e.g., Gower et al. 1990). Testing such reconstructions requires reliable paleomagnetic and geochronologic data for the middle Proterozoic. Few reliable paleomagnetic data are available for the middle Proterozoic that can be closely tied to geochronological results. In contrast, paleomagnetic data for Baltica and Laurentia indicate close agreement at $\sim 430 \mathrm{Ma}$ during the Caledonian collision (e.g., Torsvik et al. 1996), approximately 1 b.y. after these two cratons are inferred to be in roughly the same, albeit slightly rotated, relative position during the earlier (Grenvillian) collision. Clearly, in order to resolve such specialized plate tectonic shuffling more paleomagnetic data are required from both Baltica and Laurentia to confirm their relative positions during the middle Proterozoic.

The Bamble Sector and greater Baltic Shield preserve evidence of a polymetamorphic history involving two or more orogenic episodes of granulite facies metamorphism that have been roughly corre- lated with events in the Grenville Province of North America (e.g., Starmer 1985; Gower et al. 1990; Nijland and Senior 1993). As more data become available it may become possible to discriminate individual episodes of metamorphism both within and between these different orogens. The timing of Sveconorwegian metamorphism and cooling elsewhere in the Baltic shield does not appear to be contemporaneous with that observed in the Bamble Sector. The available U-Pb titanite and ${ }^{40} \mathrm{Ar} /{ }^{39} \mathrm{Ar}$ hornblende data for Sveconorwegian metamorphism and cooling in Sweden (e.g., Johansson 1990; Page et al. 1996) are roughly 100 m.y. younger than the ages determined in this study. However, the range in absolute ages for metamorphism and cooling in the Bamble Sector is remarkably similar to what is observed across the Grenville Province in Ontario (e.g., Cosca et al. 1991, 1992; Mezger et al. 1992, 1993; Tuccillo et al. 1992). These observations provide compelling evidence that Baltica and Laurentia experienced a similar or perhaps the same middle Proterozoic orogenic evolution before their eventual breakup. Further work combining high-precision geochronology with paleomagnetic data may better resolve not only the positions of Baltica and Laurentia during the middle Proterozoic but also their potential part in a global orogenic belt. 


\section{A C KNOWLEDGMENT}

Support for this research was provided by the Swiss, German, and American National Science Foundations. S. Dahlgren is thanked for discussion and assistance with sampling localities. The authors gratefully acknowledge the careful reviews of an earlier manuscript by C. Maijer, I. Starmer, and an anonymous reviewer.

Note added in proof: Bingen et al. (Precamb. Res., 1998 , v. 90, p. 153-185) have interpreted large vari- ations in geochronological data as indicating late tectonic extension across boundaries of the three major tectonic terranes (including the Bamble Sector) in South Norway. These ${ }^{40} \mathrm{Ar} /{ }^{39} \mathrm{Ar}$ data are consistent with tectonic boundaries in the Grenville Province of Ontario (e.g., Cosca et al. 1991, 1992), yet the inferred extension shows an opposite sense of younging. The mirrored geographic distribution of hornblende ${ }^{40} \mathrm{Ar} /{ }^{39} \mathrm{Ar}$ ages between continents could record successive rifting marking the initial breakup of Laurentia and Baltica.

\section{REFERENCES CITED}

Andersen, T.; Maijer, C.; and Verschure, R. H., 1995, Metamorphism, provenance ages, and source characteristics of Precambrian clastic sediments in the Bamble Sector, southern Norway: $\mathrm{Ar}, \mathrm{Sr}, \mathrm{Nd}$, and $\mathrm{Pb}$ isotope study: Petrology, v. 3, p. 321-339.

Baadsgaard, H.; Chaplin, C.; and Griffin, W. L., 1984, Geochronology of the Gloserheia pegmatite, Froland, southern Norway: Nor. Geol. Tidssk., v. 64, p. 111-119.

Barth, T. F. W., and Dons, J. A., 1960, Precambrian of southern Norway, in Holtedahl, O., ed., Geology of Norway: Nor. Geol. Unders., v. 208, p. 6-67.

Broekmans, M. A. T. M; Nijland, T. G.; and Jansen, J. B. H., 1994, Are stable isotopic trends in amphibolite to granulite facies transitions metamorphic or diagenetic?-An answer for the Arendal area (Bamble Sector, southeastern Norway) from mid-Proterozoic carbonbearing rocks: Am. Jour. Sci., v. 294, p. 1135-1165.

Bugge, J. A. W., 1943, Geological and petrographical investigations in the Kongsberg-Bamble formation: Norges. Geol. Unders. v. 160, 150 p.

Cameron, A. E.; Smith, D. H.; and Walker, R. L., 1967, Mass spectrometry of nanogram-size samples of lead: Anal. Chem., v. 41, p. 525-526.

Cherniak, D. J., 1993, Lead diffusion in titanite and preliminary results on the effects of radiation damage on Pb transport: Chem. Geol., v. 110, p. 177-194.

Clough, P. W. L., and Field, D., 1980, Chemical variation in metabasites from a Proterozoic amphibolite-granulite transition zone, south Norway: Contrib. Mineral. Petrol. v. 73, p. 277-286.

Cosca, M. A.; Essene, E. J.; Kunk, M. J.; and Sutter, J. F., 1992, Differential unroofing within the Central Metasedimentary Belt of the Grenville Orogen: Constraints from ${ }^{40} \mathrm{Ar} /{ }^{39} \mathrm{Ar}$ thermochronology: Contrib. Mineral. Petrol., v. 110, p. 211-225.

- and O'Nions, R. K, 1994, A reexamination of the influence of composition on argon retentivity in metamorphic calcic amphiboles: Chem. Geol., v. 112, p. 211-225.

; Sutter, J. F.; and Essene, E. J., 1991, Cooling and inferred uplift/erosion history of the Grenville Orogen, Ontario: Constraints from ${ }^{40} \mathrm{Ar} /{ }^{39} \mathrm{Ar}$ thermochronology: Tectonics, v. 10, p. 959-977.
Dahlgren, S.; Bogoch, R.; Margaritz, M.; and Michard, A., 1993, Hydrothermal dolomite marbles associated with charnockitic magmatism in the Proterozoic Bamble Shear Belt, south Norway: Contrib. Mineral. Petrol., v. 113, p. 394-409.

Dalziel, I. W. D., 1991, Pacific margins of Laurentia and East Antarctica-Australia as a conjugate rift pair: Evidence and implications for an Eocambrian supercontinent: Geology, v. 19, p. 598-601.

Dalrymple, G. B.; Alexander, E. C.; Lanphere, M. A.; and Kraker, G. P., 1981, Irradiation of samples for ${ }^{40} \mathrm{Ar} /{ }^{39} \mathrm{Ar}$ dating using the Geological Survey TRIGA reactor: U.S. Geol. Survey Prof. Paper 1176, 55 p.

DeWolf, C. P., and Mezger, K., 1994, Lead isotope analyses of leached feldspars: Constraints on the early crustal evolution of the Grenville Orogen: Geochim. Cosmochim. Acta, v. 58, p. 5537-5550.

Field, D., and Clough, P. W. L., 1976, K/Rb ratios and metasomatism in metabasites from a Precambrian amphibolite-granulite transition zone: Jour. Geol. Soc. London, v. 132, p. 277-288.

—, and Råheim, A., 1979, Rb-Sr total rock isotope studies on Precambrian charnockitic gneisses from south Norway: Evidence for isochron resetting during a low-grade metamorphic-deformational event: Earth Planet. Sci. Let., v. 45, p. 32-44.

, and 1 1981, Age relationships in the Proterozoic high-grade gneiss regions of southern Norway: Precamb. Res., v. 14, p. 261-275.

$\longrightarrow$, and 1983, Age relationships in the Proterozoic high-grade gneiss regions of southern Norway: Reply to "discussion and comment" by Weis and Demaiffe: Precamb. Res., v. 22, p. 157-161.

—; Smalley, P. C.; Lamb, R. C.; and Råheim, A., 1985, Geochemical evolution of the 1.6-1.5 Ga-old amphibolite-granulite facies terrain, Bamble sector, Norway: Dispelling the myth of Grenvillian highgrade reworking, in Tobi, A. C., and Touret, J. L. R., eds., The Deep Proterozoic Crust in the North Atlantic Provinces: Dordrecht, Reidel, p. 567-578.

Gall, G., and Gorbatchev, R., 1987, An outline of the Precambrian evolution of the Baltic Shield: Precamb. Res., v. 35, p. 15-52. 
Gower, C. F., 1985, Correlations between the Grenville Province and Sveconorwegian orogenic belt-implications for Proterozoic evolution of the southern margins of the Canadian and Baltic shields, in Tobi, A. C., and Touret, J. L. R., eds., The Deep Proterozoic Crust in the North Atlantic Provinces: Dordrecht, Reidel, p. 247-257.

—; Ryan, A. B.; and Rivers, T., 1990, Mid-Proterozoic Laurentia-Baltica: An overview of its geological evolution and summary of the contributions made by this volume, in Gower, C. F.; Rivers, T.; and Ryan, A. B., eds., Mid-Proterozoic Laurentia-Baltica: Geol. Assoc. Canada Spec. Paper 38, p. 1-21.

Hagelia, P., 1989, Structure, metamorphism, and geochronology of the Skagerrak Shear Belt, as revealed by studies in the Hovdefjell-Ubergsmoen area, south Norway: Unpub. Cand. Sci. Thesis, University of Oslo.

Harlov, D. E., 1992, Comparative oxygen barometry in granulites, Bamble Sector, SE Norway: Jour. Geology, v. 100, p. 447-464.

Harrison, T. M., 1981, Diffusion of ${ }^{40} \mathrm{Ar}$ in hornblende: Contrib. Mineral. Petrol., v. 78, p. 324-331.

; Duncan, I.; and McDougall, I., 1985, Diffusion of ${ }^{40} \mathrm{Ar}$ in biotite: Temperature, pressure, and compositional effects: Geochim. Cosmochim. Acta, v. 49, p. 2461-2468.

Hoefs, J., and Touret, J. L. R., 1975, Fluid inclusions and carbon isotope study from Bamble granulites (south Norway): Contrib. Mineral. Petrol., v. 52, p. 165-174.

Hoffman, P. F., 1991, Did the breakout of Laurentia turn Gondwanaland inside-out?: Science, v. 252, p. 14091412.

Johansson, А., 1990, Age of the Önnestad Syenite and some gneissic granites along the southern part of the Protogine Zone, southern Sweden, in Gower, C. F.; Rivers, T.; and Ryan, A. B., eds., Mid-Proterozoic Laurentia-Baltica: Geol. Assoc. Canada Spec. Paper 38, p. 131-148.

Kihle, J., and Bucher-Nurminin, K. B., 1992, Orthopyroxene-sillimanite-sapphirine granulites from the Bamble granulite terrane, southern Norway: Iour. Metam. Geol., v. 10, p. 671-683.

Kirschner, D. L.; Cosca, M. A.; Hunziker, J. C.; and Masson, H., 1996, Staircase ${ }^{40} \mathrm{Ar} /{ }^{39} \mathrm{Ar}$ spectra of finegrained white mica: Timing and duration of deformation and empirical constraints on argon diffusion: Geology, v. 24, p. 747-750.

Knudsen, T. L., 1996, Petrology and geothermobarometry of granulite facies metapelites from the Hisøy-Torungen area, south Norway: New data on the Sveconorwegian P-T-t path of the Bamble Sector: Jour. Metam. Geol., v. 14, p. 267-287.

Kullerud, L., and Dahlgren, S. H., 1993, Sm-Nd geochronology of Sveconorwegian granulite facies mineral assemblages in the Bamble Shear Belt, South Norway: Precamb. Res. v. 64, p. 389-402.

- and Machado, N., 1991, End of a controversy: $\mathrm{U}-\mathrm{Pb}$ geochronological evidence for significant Grenvillian activity in the Bamble area, Norway. Terra Abstract, v. 4, p. 543.
Ludwig, K. R., 1980, Calculation of uncertainties of U-Pb isotope data: Earth Planet. Sci. Lett., v. 46, p. 212220.

- 1982, A computer program to convert raw U-Th$\mathrm{Pb}$ isotope ratios to blank-corrected isotope ratios and concentrations with associated error-correlations: U. S. Geol. Survey Open-File Rep. 82-820, 24 p.

Manhès, G.; Allègre, C. J.; and Provost, A., 1984, U-Th$\mathrm{Pb}$ systematics of the eucrite "Juvinas": Precise age determination and evidence for exotic lead: Geochim. Cosmochim., Acta, v. 48, p. 2247-2264.

Mattinson, J. M., 1986, Geochronology of high-pressurelow-temperature Franciscan metabasites: A new approach using the U-Pb system: Geol. Soc. America Mem. 164, p. 95-105.

Mezger, K.; Essene, E. J.; and Halliday, A. N., 1992, Closure temperatures of the Sm-Nd system in metamorphic garnets: Earth Planet. Sci. Lett., v. 113, p. 397410.

— G. N., 1991, U-Pb garnet, titanite, monazite, and rutile ages: Implications for the duration of high-grade metamorphism and cooling histories, Adirondack Mts., New York: Jour. Geology, v. 99, p. 415-428.

; van der Pluijm, B. A.; Essene, E. J.; Halliday, A. N., 1993, U-Pb geochronology of the Grenville Orogen of Ontario and New York: Constraints on ancient crustal tectonics: Contrib. Mineral. Petrol., v. 114, p. 13-26.

Moores, E. M., 1991, Southwest U.S.-East Antarctic (SWEAT) connection: A hypothesis: Geology, v. 19, p. 425-428.

Nijland, T. G.; Liauw, F.; Visser, D.; Maijer, C.; and Senior, A., 1993, Metamorphic petrology of the Froland corundum-bearing rocks: The cooling and uplift history of the Bamble Sector, South Norway: Nor. Geol. Unders., v. 424, p. 51-64.

- , and Maijer, C., 1993, The regional amphibolite to granulite facies transition at Arendal, Norway: Evidence for a thermal dome: Neues Jahrb. Miner. Abh., v. 165, p. 191-221.

_ facies metamorphism of polyphase migmatites and basic dikes, south Norway: Jour. Geology, v. 99, p. $515-525$.

O'Nions, R. K., and Baadsgaard, H., 1971, A radiometric study of Polymetamorphism in the Bamble Region, Norway: Contrib. Mineral. Petrol., v. 34, p. 1-21.

; Morton, R. D.; and Baadsgaard, H., 1969b, Potassium-argon ages from the Bamble Sector of the Fennoscandian shield in south Norway: Nor. Geol. Tidssk., v. 49, p. 171-190.

_ ; Smith, D. G. W.; Baadsgaard, H.; and Morton, R. D., 1969a, Influence of composition on argon retentivity in metamorphic calcic amphiboles from south Norway: Earth Planet. Sci. Lett., v. 5, p. 339-345.

Page, L. M.; Stephens, M. B.; and Wahlgren, C. H, 1996, ${ }^{40} \mathrm{Ar} /{ }^{39} \mathrm{Ar}$ geochronological constraints on the tectonothermal evolution of the Eastern Segment of the Sveconorwegian Orogen, south-central Sweden, in 
Brewer, T. S., ed., Precambrian crustal evolution in the North Atlantic Region: Geol. Soc. (London) Spec. Publ. 112, p. 315-330.

Park, R. G., 1992, Plate kinematic history of Baltica during the Middle to Late Proterozoic: A model: Geology, v. 20, p. $725-728$.

Parrish, R. R., 1990, U-Pb dating of monazite and its application to geological problems: Can. Jour. Earth Sci., v. 27 , p. $1431-1450$.

Pineau, F.; Javoy, M.; Behar, F.; and Touret, J., 1981, La géochimie isotopique du faciès granulite du Bamble (Norvège) et l'origine des fluides carbonés dans la croûte profonde: Bull. Mineral., v. 104, p. 630-641.

Samson, S. D., and Alexander, E. C., 1987, Calibration of the interlaboratory ${ }^{40} \mathrm{Ar} /{ }^{39} \mathrm{Ar}$ dating standard, MMhb-1: Chem. Geol., v. 66, p. 27-34.

Smalley, P. C., 1990, Rb-Sr systematics of a Gardar-age layered alkaline monzonite suite in southern Norway: A reply: Jour. Geology, v. 98, p. 123-128.

— Field, D.; Lamb, R. C.; and Clough, P. W. L., 1983, Rare earth, Th-Hf-Ta, and large-ion lithophile element variations in metabasites from the Proterozoic amphibolite-granulite transition zone at Arendal, south Norway: Earth. Planet. Sci. Lett., v. 63, p. 446458.

Starmer, I. C., 1985, The evolution of the south Norwegian Proterozoic as revealed by the major and megatectonics of the Kongsberg and Bamble Sectors, in Tobi, A. C., and Touret, J. L. R., eds., The Deep Proterozoic Crust in the North Atlantic Provinces: Dordrecht, Reidel, p. 259-290.

— $1990, \mathrm{Rb}-\mathrm{Sr}$ systematics of a Gardar-age layered alkaline monzonite suite in southern Norway: A discussion: Iour. Geology, v. 98, p. 119-123.

- 1991, The Proterozoic evolution of the Bamble Sector shear belt, southern Norway: Correlations across southern Scandinavia and the Grenvillian controversy: Precamb. Res., v. 49, p. 107-139.

Steiger, R. H., and Jäger, E., 1977, Subcommission on geochronology: convention on the use of decay constants in geo- and cosmochronology: Earth Planet. Sci. Lett., v. 36, p. 359-362.

Tilton, G. R., 1973, Isotopic lead ages of chondritic meteorites: Earth Planet. Sci. Lett., v. 19, p. 321-329.

Torsvik, T. H.; Smethurst, M. A.; Meert, J. G.; Van der Voo, R.; McKerrow, W. S.; Brasier, M. D.; Sturt, B. A.; and Walderhaug, H. J., 1996. Continental break-up and collision in the Neoproterozoic and Paleozoic-a tale of Baltica and Laurentia: Earth Sci. Rev., v. 40, p. 229-258.

Touret, J., 1968, The Precambrian metamorphic rocks around the Lake Vegår (Aust-Agder, southern Norway): Nor. Geol. Unders., v. 257, p. 1-45.

_, $1971 a$, Le faciès granulite en Norvège méridionale. I. Les associations minéralogiques: Lithos, v. 4, p. 239-249.

, 1971b, Le faciès granulite en Norvège méridionale. II. Les inclusions fluides: Lithos, v. 4, p. 423-436.

- 1985, Fluid regime in southern Norway: The record of fluid inclusions, in Tobi, A. C., and Touret, J. L. R., eds., The Deep Proterozoic Crust in the North Atlantic Provinces: Dordrecht, Reidel, p. 517-549.

Touret, J., and Olsen, S. N., 1985, Fluid inclusions in migmatites, in Ashworth, J. R., ed., Migmatites: Glasgow, Shiva, p. 265-288.

Tuccillo, M. E.; Mezger, K.; Essene, E. J.; and van der Pluijm, B. A., 1992, Thermobarometry, geochronology, and the interpretation of P-T-t data in the Britt Domain, Ontario Grenville Orogen, Canada: Jour. Petrol., v. 33, p. 1225-1259.

Verschure, R. H., 1985, Geochronological framework for late Proterozoic evolution of the Baltic Shield in South Scandinavia, in Tobi, A. C., and Touret, J. L. R., eds., The Deep Proterozoic Crust in the North Atlantic Provinces: Dordrecht, Reidel, p. 381-410.

Villa, I. M.; Grobéty, B.; Kelley, S. P.; Triglia, R.; and Wieler, R., 1996, Assessing Ar transport paths and mechanisms in the McClure Mountains hornblende: Contrib. Mineral. Petrol., v. 126, p. 67-80.

Visser, D., and Senior, A., 1990, Aluminous reaction textures in orthoamphibole-bearing rocks: The pressuretemperature evolution of the high-grade Proterozoic of the Bamble sector, south Norway: Iour. Metam. Geol., v. 8, p. 231-246.

Visser, D.; Thijssen, P. H. M.; and Schumacher, J. C., 1992, Högbomite in sapphirine-bearing rocks from the Bamble Sector, south Norway: Mineral. Mag., v. 56, p. 343-351.

Weis, D., and Demaiffe, D., 1983, Age relationships in the Proterozoic high-grade gneiss regions of southern Norway: Discussion and comment: Precamb. Res., v. 22, p. 149-155. 